ISSN 1991- 8690

Website: http://jsci.utq.edu.iq
الترقيم الدولي • 1991 - 1979

Email: utjsci@utq.edu.iq

\title{
Isolation and identification of bacterial contamination of raw meat in Thi-Qar province markets
}

\author{
Basim Abdulhussein Jarullah \\ College Of Veterinary Medicine- University Of Thi-Qar \\ Email: dr.basimj@gmail.com
}

\section{Summary}

Meat considers a favorite environment for bacterial growth due to rich composition with protein, fats, minerals, vitamins and other essential materials requirements for microorganism growth. Study concluded isolation and bacterial account of meat in Thiqar city markets. Study extends from November2014- March 2015. Thirty samples of meat (10 from beef meat, 10 from sheep and 10 from poultry meat). Bacterial account shown that the highest contamination of meat samples found in sheep meat $16^{*} 10^{6} \mathrm{CUF} / \mathrm{g}$ (more than standard parameters of healthy suitable meat for human consumption) while the lowest bacterial account found in poultry meat $93 * 10^{2} \mathrm{CUF} / \mathrm{g}$. Isolation and identification of bacteria by morphological, differential media, biochemical tests and Gram stain results showed that prodomenet bacteria were E.coli, Klebseilla, Staphylococcus aureas, Shegilla, Salmonella spp., Bacillus cereus, Enterobacter, Proteus, Micrococcus, Pseudomonas spp. and streptococcus spp. The predominant bacteria was E. coli about $35 \%$ in all samples, Followed by staphylococcus spp. 25\%. Salmonella spp.1.2\% isolated only from chicken meat samples.

Key words: raw meat, bacteria, Thi-Qar, markets

$$
\begin{aligned}
& \text { عزل وتشخيص البكتريا الملوثة للحوم في اسواق محافظة ذي قار } \\
& \text { باسم عبدالحسين جاراله } \\
& \text { كلية الطب البيطري - جامعة ذي قار }
\end{aligned}
$$

$\underline{\text { الخلاصة }}$

يعتبر اللحم بيئة ملائمة لنمو الاحياء المجهرية وذلك لطبيعة تركيبة الغنية بالبروتين والدهون والمعادن والفيتامينات اضافة الى مواد الاخرى للنمو

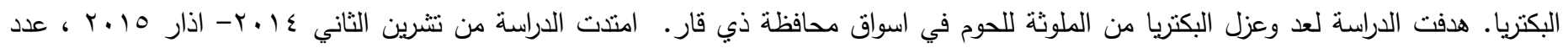

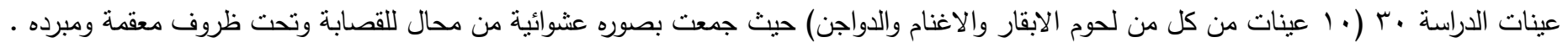
تم عد البكتريا الملوثة للحوم بعد عمل عدة تخافيف من العينات حيث ظهر ان اعلى نسبة للبكتريا في عينات لحوم الاغنام 16"106 CUF/gm بينما كان

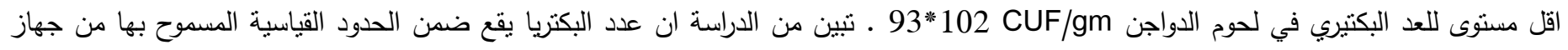
التقييس والسيطرة النوعية للقوانين العراقية. بعد اجراء الفحوصات المظهرية العانية للمستعمرات النامية وباستخدام اوساط تفريقيه مختلفة والاختبارات الكيميائية

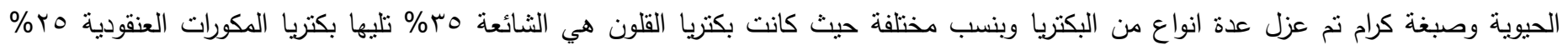

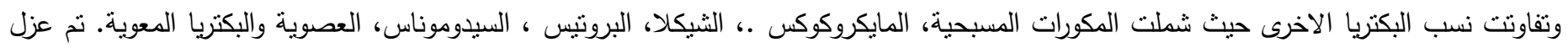

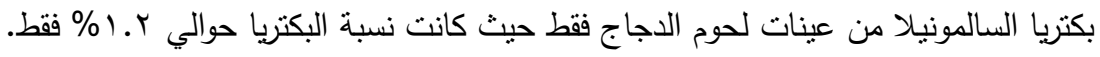




\section{Introduction}

Meat is an edible animal flesh which comprises principally the muscular tissue, and also includes internal organ called viscera such as heart, liver, kidney, intestine and bladder. [Adams and. Moss, 1999; Okala and Reedi, 2001]. Relate that the bulk of meat is derived from goat, cattle, pig, sheep, and poultry. According to Ikeme (1990) the chemical composition of meat varies considerably with age, species, degree of fatness of animal, the part of carcass involved etc. Because of the enormous value of meat in the diet, there exist large markets for meat and meat products worldwide at varying money value hence their demands increase day by day across the globe.

Meat products are obtained when raw meat or preserved meat (cured meat) are altered in form by grinding, pressing, drying and other processes then augmented in flavour by smoking, spicing or blending with other food. These meat products are subjected to combination of several basic processing steps before reaching their final form. Therefore meat products are also termed as processed meat Micro-organisms that occur in meat and meat products most times are responsible for food borne illness. These microorganisms are Bacillus sp, Clostridium spp, Escherichia coli, Salmonella sp, Shigella sp, Staphylococcus aureus, Streptococcus pyogenes, Proteus, Pseudomonas, Leuconostoc, Lactobacillus spp, Micrococcus, Mycobacterium sp, Vibrio sp etc. [Baird-Parker, 1991].Salmonella may be transferred from raw meat to cooked meat by hands, surfaces or utensils [Jay, 2000]. Of all microorganism bacteria are the greatest importance, some bacteria are not infectious on their own, but when they multiply in food they eject toxin, that poisons human when consumption. Also processing practices can exacerbate contamination through poor hygiene (Al.Tai, 1986; Biss, and Hathaway, 1996; Galland, 1998).

The chief constituents of meat are water, protein and fat, phosphorus, iron and vitamins are also contained in meat. The major primary unit of meat is called carcass. It represents the ideal meat after head, hide, intestine, blood. The edible parts of a carcass include lean flesh, fat flesh and edible glands or organs such as heart, liver, kidney tongue and brain. Meat is considered as the most nutritive source of protein consumed by humans. Age and sex of the animal has a major influence on the quality of meat that is produced from animals (Rao et al., 2009).
Notwithstanding the major role meat play in our meals, it can also serve as a rich medium of growth for harmful microorganisms. Meat infected with microorganisms is the cause of many food-borne diseases (WHO, 1997). The source of these pathogenic microorganism may be the animals themselves or from outside. The surroundings where these animals are kept as well as the way they are processed after slaughtering can also result in contamination with microorganisms (Adeyemo, 2002). Meat infected with microorganisms is normally poor in quality (Mukhopadhyay, 2009).

\section{Methods}

Thirty meat samples from the various markets of Thiqar province were collected into sterile plastic bags, stored at $4{ }^{\circ} \mathrm{C}$ in ice chest filled with ice and transported to the laboratory for immediate analysis. Samples included 10 from beef meat, 10 from sheep meat and 10 from poultry meat (5 grams for each sample). Study extended from November 2014- March 2015. Peptone water used as diluent $\left(10^{-1}, 10^{-2}, 10^{-3}, 10^{-}\right.$ ${ }^{4}, 10^{-5}$ ) duplicate plate were culture from each dilution according to (APHA, 1986).

\section{1-Total Viable Bacteria Count}

One $\mathrm{ml}$ of aliquots of each dilution was transferred in septic conditions to sterile petri-plates and mixed with about $15 \mathrm{ml}$ of nutrient agar tempered to $45-$ $50 \mathrm{C}^{\circ}$. The cooled plat were inverted and incubated at $37 \mathrm{C}^{\circ}$ for $48 \mathrm{hr}$.Following the incubation the colonies on duplicate plates (Containing 30-300 colonies) were counted using the Quebec colony counter. The concentration of bacteria in the original sample was calculate by multiplying the number of colonies on a dilution plate by the corresponding dilution factor and the number of microbes were expressed as colony forming unites (CUF) per gram (APHA, 1985). More of 300 colony in one plate negligible.

2- Bacterial identification was conducted by standard morphological and biochemical characters of isolates (MOCM, 2002).

\section{Results}

Outcomes of bacterial accounts in different serials of samples concentrations shown in table 1. Which reveal that the highest contamination of meat samples occur in sheep meat $16^{*} 10^{6} \mathrm{CFU} / \mathrm{g}$, while the lowest bacterial account found in beef meat $54^{*} 10^{2}$. 
Table (1) bacterial account in different serials of dilutions

\begin{tabular}{|l|l|}
\hline Sample & $\begin{array}{l}\text { Mean of Total Bacterial } \\
\text { Count (CFU/g) }\end{array}$ \\
\hline Beef meat & $76^{*} 10^{2}$ \\
\cline { 2 - 2 } & $52 * 10^{3}$ \\
\cline { 2 - 2 } & $54 * 10^{2}$ \\
\cline { 2 - 2 } & $62 * 10^{4}$ \\
\hline Sheep & $16^{*} 10^{6}$ \\
\cline { 2 - 2 } & $77 * 10^{5}$ \\
\cline { 2 - 2 } & $51 * 10^{4}$ \\
\cline { 2 - 2 } & $81 * 10^{5}$ \\
\hline Poultry & $15.3^{*} 10^{3}$ \\
\cline { 2 - 2 } & $73 * 10^{4}$ \\
\cline { 2 - 2 } & $93 * 10^{2}$ \\
\cline { 2 - 2 } & $57 * 10^{4}$ \\
\hline
\end{tabular}

The isolates were identified as Staphyloccus aureus, streptococcus, shegilla, Klebsiella, Enterobacter spp, Escherichia coli, Salmonella spp, , Pseudomonas spp, Bacillus cereus and Proteus spp. the predominant bacteria of all samples was E. coli about $35 \%$. Salmonella spp. were isolated only from chicken sample, they about $2.5 \%$ only. Percentage of bacteria in different samples revealed in table 2.

Table (2) percentages of bacteria genera in different meat samples

\begin{tabular}{|l|c|l|}
\hline Samples origin & Bacteria isolates & $\begin{array}{l}\text { Percentage of bacteria } \\
\text { related to other isolates }\end{array}$ \\
\hline \multirow{4}{*}{ Beef, sheep and poultry } & E. coli & $35 \%$ \\
\cline { 2 - 3 } & Staphylococcus & $25 \%$ \\
\cline { 2 - 3 } & Enterobacter & 11.2 \\
\cline { 2 - 3 } & Klebseilla & 5.6 \\
\cline { 2 - 3 } & Streptococcus & 5.4 \\
\cline { 2 - 3 } & Shegilla & $4.9 \%$ \\
\cline { 2 - 3 } & Micrococcus & $4.3 \%$ \\
\cline { 2 - 3 } & $\begin{array}{c}\text { Pseudomonas, Bacillus } \\
\text { cereus, Proteus }\end{array}$ & $5.4 \%$ \\
\hline $\begin{array}{l}\text { isolated from poultry meat } \\
\text { only }\end{array}$ & \begin{tabular}{c} 
Salmonella spp. \\
\hline
\end{tabular} & 1.2 \\
\hline
\end{tabular}

\section{Discussion}

The presence of bacteria in meat has been widely reported from different parts of the world (Holds, 2007; Kinsella et al., 2008). Some groups recognized the presence of viable bacteria, especially Gram-negative organisms from $10^{6}$ to $10^{9}$, as an indication of open-air meat spoilage (Eribo and Jay, 1986), while others argued this assertion and considered the presence of a high number of background organisms as a pathogenreduction strategy due to the organisms' antagonistic effect against pathogenic bacteria and thus safer for meat quality. Therefore, it is considered that fresh meat that contains $10^{5}-10^{6}$ of background organisms are inherently safer than those that contain less bioload; however, this hypothesis applies only to harmless bacteria (Jay, 1996). In order to address the issue in the view of our local scenario, the organisms were identified. Results indicated the predominance of Gram-negative organisms such as Salmonella, Shigella, and Escherichia coli as reported by other groups (Zweifel, 2008). These organisms are already involved in various infectious disease outbreaks in Karachi (Luby et al. 1993; Nasim and Vahidy, 1998 ; Nasir, Shah and Rashid, 1999). The presence of zoonotic bacteria such as Brucella and Listeria indicates poor ante-mortem inspection of the animals as well as unhygienic meat processing (Lacerda et al. 1997; Barros et al. 2007). In one Iraqi study that compared imported meat to local meat, the demonstrated that predominant bacteria were E. coli then Staphylococcus spp. also study revealed the count of bacterial contamination near the standard Iraqi values, this agreed with our study.( Samir, et al. 2013). Incidences of E. coli, Enterobacter spp and other index of poor sanitary quality found in this study are in agreement with previous studies. E. coli $\mathrm{O} 157$ outbreaks due to plants and animal produce have become increasingly common (Schroeder et al., 2005). While half of produce associated outbreaks were due to kitchen-level crosscontamination, which calls for further prevention efforts targeting food preparers, the other half were due to produce already contaminated with E. coli $\mathrm{O} 157$ before purchase (Schroeder et al., 2005). Salmonella spp. are poorly isolate from beef and sheep meat while it is easy to isolate from poultry meat. Chicken meat consider main sources of infection for human and animals. In previous Iraqi research no isolates of Salmonella from local and imported beef and sheep meat.( Samir, et al. 2013). The total number of bacterial account in chicken meat was very low this may related to easy freezing and treating with poultry meat due to small size of carcasses compare to beef and sheep meat.

\section{References}

Adams M. R.and M.O.Moss. Food microbiology. The Royal Society of Chemistry, Thomas Graham house, Service Park, Cambridge, UK. 1999, 192202.

Adeyemo, O. K. (2002). Unhygienic operation of a city abattoir in South Western Nigeria: Environmental Implication. African Journal of Environmental Assessment and Management. 4(1), pp. 23-28. 
Al.Tai, M.A.J.(1986). Fish and meat Technology. Dar Al. kutob for press .Basrah Univ.

American Public Health Association (APHA) .(1985). Standard methods for the examination of dairy product ,15th. American public Health Association .New-York.

Baird-Parker A.C. (1993). Food and microbiological risks. Fred Griffith Review lecture In : Journal of Microbiology (1994) 140:687-695.

Barros MAF, Nero LA, Silva LC, d'Ovidio L, Monteiro FA, Tamanini R, Fagnani R, Hofer E, Beloti V (2007) Listeria monocytogenes: Occurrence in beef and identification of the main contamination points in processing plants. Meat Sci 76:591-596.

Biss, M.E.and Hathaway ,S.C.(1996).Effect of preslaughter washing of lambs on the microbiological and visible contamination of the carcasses Vet.Rec.138:82-6.

Eribo BE and Jay JM (1985) Incidence of Acinetobacter spp. and Other Gram-Negative, Oxidase-Negative Bacteria in Fresh and Spoiled Ground Beef. App Env Microbiol 49: 256-257.

Galland,J.C(1998).Risks and prevention of contamination of beef carcasses during the slaughter process in the united states of America. Rev. sci. off. Int. Epiz.16:395-404

Holds G, Pointon A, Lorimer M, Kiermeier A, Raven G, Sumner J (2007) Microbial profiles of carcasses and minced meat from kangaroos processed in South Australia. Int J Food Microbiol 123: 88-92.

Ikeme. A.I. Meat Science and Technology. A comprehensive approach. Africana FEP publishers Ltd. Onitsha, Nigeria1990.

Ikeme. I. A. Meat Science and Technology. A comprehensive approach. J.M. Jay. Modern Food Microbiology. 6thEdition. Aspen Publishers Inc. Jay JM (1996) Microorganisms in fresh ground meats: the relative safety of products with low versus high numbers. Meat Sci 43: 59-66.

Kinsella KJ, Prendergast DM, McCann MS, Blair IS, McDowell DA, Sheridan JJ (2008) The survival of Salmonella enterica serovar Typhimurium DT104 and total viable counts on beef surfaces at different relative humidities and temperatures. $\mathbf{J}$ App Microbiol 106: 171-180.
Lacerda LM. Alves LMC, Mathias LA, Rodrigues ALB, Almeida FM (1997) Brucelose em trabalhadores de matadouros do município de São Luis, MA. Hig Aliment 14: 62-65.

Luby SP, Faizan MK, Fisher-Hoch SP, Syed A, Mintz ED, Bhutta ZA and Mccormick JB (1998) Risk factors for typhoid fever an endemic setting, Karachi, Pakistan. Epidemiol Infect 120: 129138.

Manual of Clinical Microbiology (MOCM). (2002) 7th edition. Washington DC USA American Society for Microbiology Press. 442-631p.

Mukhopadhyay, H. K., Pillai, R. M., Pal, U. K. and Ajay, V. J. (2009). Microbial quality of fresh chevon and beef in retail outlets of Pondicherry Tamilnadu. Journal of Veterinary and Animal Sciences. 5(1), pp. 33-36.

Nasim RB and Vahidy R (1993) Human listerial meningitis: reported from Karachi, Pakistan J Isl Acad Sci 6: 253-258.

Nasir AA, Shah MA and Rashid M (1999) Current status of Brucellosis in cattle in various government livestock farms in Panjab. International J Agri Biol 1: 337-338.

Okala, I. and A.Reedi.A. Comprehensive Approach Africana Publishers Limited-Nigeria 2001, 3335.

Rao VA, Thulasi G, Ruban SW. Meat quality characteristics of non-descript buffalos as affected by age and sex. World Applied Science Journal, 2009; 1058-1065.

Samir A. A. Abid A., Abdul A. j., Salah M. (2013).The Bacteria Contamination of Red Local and Imported Meat. Iraqi journal of science, vol. 54.No.2. Pp:249-254.

Schroeder CM, Naugle AL, Schlosser WD, Hogue AT, Angulo FJ, Rose JS, et al. Estimate of illnesses from Salmonella enteritidis in eggs, United States, 2000. Emerging Infectious Diseases, 2005 January [cited 2009 August 18]. Availablefrom http://www.cdc.gov/ncidod/EID/vol11no01/0 4-0401.htm

WHO (1997). Food safety and foodborne diseases. World Health Statistics Quarterly. 50(1/2).

Zweifel C, Fischer R, Stephan R (2008) Microbiological contamination of pig and cattle carcasses in different small-scale Swiss abattoirs. Meat Sci 78: 225-231. 